$12-4-2004$

\title{
The Formation of Christianity in Antioch: A Social-Scientific Approach to the Separation Between Judaism and Christianity
}

Matt Jackson-McCabe

Cleveland State University, m.jacksonmccabe@csuohio.edu

Follow this and additional works at: https://engagedscholarship.csuohio.edu/clrelst_facpub

Part of the Christianity Commons

How does access to this work benefit you? Let us know!

Publisher's Statement

This review was published by RBL @2004 by the Society of Biblical Literature.

\section{Recommended Citation}

Jackson-McCabe, M. 2004. Review of The formation of Christianity in antioch: A social-scientific approach to the separation between Judaism and Christianity, by Magnus Zetterholm. Review of Biblical Literature [http://bookreviews.org].

This Book Review is brought to you for free and open access by EngagedScholarship@CSU. It has been accepted for inclusion in Religious Studies Faculty Publications by an authorized administrator of EngagedScholarship@CSU. For more information, please contact library.es@csuohio.edu. 
RBL $12 / 2004$

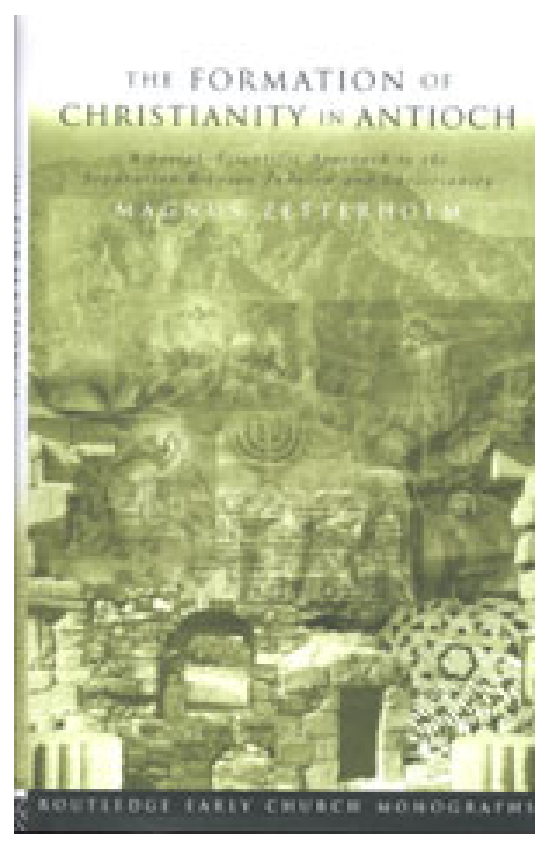

\section{Zetterholm, Magnus}

The Formation of Christianity in Antioch: A SocialScientific Approach to the Separation between Judaism and Christianity

Routledge Early Church Monographs

London: Routledge, 2003. Pp. xiv +272 . Hardcover. $\$ 80.00$. ISBN 0415298962 .

\section{Matt Jackson-McCabe \\ Niagara University \\ Lewiston, NY 14109}

Historical analysis of the relationship between Judaism and Christianity in the first centuries of the Common Era, long a central concern in the study of Christian origins, seems to be approaching a crossroads. The general "Parting of the Ways" model that has dominated scholarship since the Second World War has become the object of substantial and serious criticism (see, e.g., Adam H. Becker and Annette Yoshiko Reed, eds., The Ways That Never Parted: Jews and Christians in Late Antiquity and the Early Middle Ages [TSAJ 95; Tübingen: Mohr Siebeck, 2003]). And Paul, traditionally regarded as a (if not the) decisive figure in this respect, has himself been read "within Judaism" in an increasing number of recent studies (see on this John G. Gager, Reinventing Paul [Oxford: Oxford University Press, 2000]). Yet another sign of the healthy reconsideration of conventional wisdom on this matter is the revised version of Magnus Zetterholm's doctoral dissertation (Lund University, 2001), which brings current sociological theory to bear on the separation as it occurred in one specific location: Antioch-on-the-Orontes. The book's provocative thesis is that the "parting of the ways," at least here, was essentially an inner-Christian affair: the result of a conscious effort by "Jesus-believing Gentiles" to dissociate themselves from the "Jesus-believing Jews" to whose community they were attached. What is more, it was not Paul who laid the groundwork for this separation, but James. 
In the first chapter, Zetterholm explains that the approach to the general problem of the separation of Judaism and Christianity taken by James D. G. Dunn's The Parting of the Ways (London: SCM, 1991) is inadequate on three scores: its limited focus on "ideological aspects" (Zetterholm will deal with these, but "within a sociological framework" [4]); its notion that Paul meant to replace "the Torah with faith in Christ for both Jews and Gentiles" (Zetterholm assumes, with Gager, that Paul envisioned separate paths to salvation for Jews and Gentiles [5]); and, most interestingly, its assumption that "the original Jewish and Gentile identities of the adherents to the Jesus movement are transformed into a common Christian identity" (Zetterholm prefers to speak of "Jesusbelieving Jews" and "Jesus-believing Gentiles" [6, emphasis original]). Since the separation cannot in any case be assumed to have occurred uniformly everywhere, he limits his study to one location: Antioch.

Given the paucity and questionable reliability of the sources, Zetterholm finds sociological theories to be indispensable "gap-fillers," indeed, "providers of information" in those cases where "the alternative," given the state of the evidence, "is to say nothing" $(10,11)$. He thus proposes a four-part method involving (1) the assumption of the general theoretical perspective of the sociology of knowledge as presented in Peter L. Berger and Thomas Luckman, The Social Construction of Reality (London: Penguin, 1991); (2) the use of more specific sociological theories and models to illuminate particular problems; (3) comparative study of other data from antiquity; and, of course, (4) analysis of the primary source material from Antioch. A case is considered made "if we find something in texts about the local situation in Antioch that makes sense from an underlying socialscientific perspective, and if this text can be analyzed with modern theories in order to extract more information from it, and if we also find expressions of the same phenomenon in other ancient texts dealing with other locations" (14).

Chapter 2 provides a broad treatment of the history of, and sociopolitical conditions in, ancient Antioch in order to provide a general context for the study. The most important points would seem to be the following. All inhabitants of Antioch, generally speaking, were required to participate in the city and imperial cults. The Jewish community, which like other foreign cults was constituted as a collegium, was the sole exception. The established social networks provided by Antioch's various collegia-including the Jewish one, with its estimated twenty to thirty synagogues - would have been attractive to the city's substantial immigrant population.

The third chapter examines religious differentiation within the Jewish population of Antioch, with special attention to the matter of its relations with the dominant Hellenistic society. The sources from Antioch are scanty, so Zetterholm's method is clearly on display. Gaps left by the primary sources are filled in by a contemporary theory of 
religious change in migrant populations and a sociological model of assimilation, with these in turn checked against comparative materials from Hellenistic Egypt. His starting point is the assumption that "Diaspora status ... created certain differences in the religiousness of Diaspora Judaism" as compared to that in Palestine due to a change in what Berger and Luckman call plausibility structures. Life in a religiously diverse environment, particularly where one is in a minority, in other words, presents ongoing challenges to one's commitment to the construction of reality presented by one's own religion. Sociological studies suggest that "some people tend to be more religious, some become less religious, and still others become religious in a new way" in such situations (97). These generalizations are then significantly nuanced vis-à-vis a model of assimilation that Zetterholm adapts "to suit the conditions during antiquity" (98).

Drawing primarily on Josephus's account of the public renunciation of Judaism by a prominent Antiochene Jew named Antiochus in 66 C.E., and the massacre of Jews that resulted from his accusation that the Jewish community had been conspiring to burn the city, Zetterholm finds evidence both for total assimilation and for intensified religious commitments with mere acculturation (i.e., "familiarity with the cultural matrix of the host society" [68]) on the part of the Jews of Antioch. Evidence of "innovative manifestations of Judaism" (90-91), on the other hand, is found both in the messianic Jesus movement and (rather more vaguely) in the creation of a "Hellenistic Judaism"both of which, he argues, went beyond mere acculturation to form "[p]rimary relationships with members of the host society" even while drawing the line at intermarriage (68). Finally, it is argued that "the evidence as well as sociological considerations speak strongly in favor" of viewing individual synagogues in Antioch as being dominated by different forms of Jewish ideology (91). Zetterholm suggests that what Luke called the Antiochene ekklesia was in fact "a synagogue consisting mainly of Jesus-believing Jews" (93) and that the name Xpıorıavós, first attested in Antioch, likely originated as "an intra-Jewish designation for a Jewish messianic synagogue" there (96) - roughly analogous to the description of synagogues elsewhere as being of Augustans, Agrippans, or Vernaclesians.

In chapter 4 Zetterholm zeroes in on the nature of the relationship between Jews and Gentiles - including "Jesus-believing Jews" and "Jesus-believing Gentiles"-in Antioch. From the Gentile side he finds clear evidence of both anti-Judaism (he would even say anti-Semitism; see 112-14) and a certain attraction to Judaism. The latter is particularly evident on the part of those "God-fearers" who, he argues, were generally characterized by simultaneous attachment to a synagogue community and involvement in the religion of the polis. ("Only formal conversion to Judaism, if that was possible, would exempt a Gentile born person from his or her [civic] religious obligations" [128].) Such Gentile attraction to Judaism is also clear in case of the Jesus-believing Jews, who however

This review was published by RBL (C2004 by the Society of Biblical Literature. For more information on obtaining a subscription to RBL, please visit http://www.bookreviews.org/subscribe.asp. 
exacted a higher-than-usual price on Gentiles by requiring them to renounce GrecoRoman religion entirely.

Turning to the so-called "incident at Antioch," Zetterholm proposes "a different interpretive frame" (135, emphasis original) in which to view what little information the sources provide regarding this specific instance of Jew-Gentile interaction. His reconstruction involves a complex series of arguments but boils down to the following main points. First, he emphasizes the eschatological dimension of the issue of Gentiles within the context of a Jewish messianic group. While ancient Jewish texts reveal eschatological expectations for Gentiles ranging from salvation to destruction, "the early Jesus movement certainly seems to have been influenced by traditions with a positive attitude toward Gentiles," as evidenced by their Gentile mission (139). Second, even in Jewish texts that envisioned salvation for Gentiles, "the question of how this would come about had not been reflected upon" (142; cf. 156). If Jewish salvation is guaranteed by participation in the covenant, no analogous mechanism was specified in the case of Gentiles, who were generally expected to be saved precisely as Gentiles rather than as members of the covenant people. Third, the so-called "apostolic decree" is historical. Fourth, for Jews in general, common meals with Gentiles were "perfectly possible," particularly if they occurred within a Jewish setting (155). In fact, it is suggested that the occurrence of such meals among believers in Jesus before the arrival of James's representatives "may have had nothing to do with the specific theology of Paul and the Jewish-believing Jews," but rather simply been "part of a local Antiochean halakhah prevalent among Hellenized Jews in general" (159-60).

With this as his framework, Zetterholm proceeds to analyze the conflict itself. As he sees it, the ultimate cause of the problem was the lack of any established understanding of Gentile salvation in contemporary Jewish eschatology - a problem that became quite pressing within a messianic movement for whom these issues were no longer abstract, in which "[i]deology had to be transformed to social reality" (140). Paul, "embrac[ing] the pattern of covenantal nomism," proposed a radical solution: "in order to be saved, Gentiles had to be included in the covenant" (156) — only precisely as Gentiles, not as circumcised converts, lest Israel's God seem to be merely the God of the Jews rather than the God of all. James, however, worked with a different model. He "considered the Jesusbelieving Gentiles to be connected to the Jewish community as god-fearers" and believed they would be saved as such — not as actual members of the covenant people (161, emphasis original). With "too close an association with Gentiles" perhaps "regarded as a threat to Judaism itself," James reacted by demanding that Jesus-believing Jews and Jesus-believing Gentiles form separate commensality groups, and it was his position that was adopted (161). Precisely in his victory do "we find the embryo of what later became a virtual separation between Jews and Gentiles, between Judaism and Christianity" (166).

This review was published by RBL @ 2004 by the Society of Biblical Literature. For more information on obtaining a subscription to RBL, please visit http://www.bookreviews.org/subscribe.asp. 
Chapter 5 explains how subsequent social and political circumstances led to a final separation of the two groups created by James. With a theory of social movements as his model, Zetterholm argues that this separation was the result of a conscious effort on the part of the Gentile believers to become recognized as a collegium independent from that of Judaism, but nonetheless sharing its exemption from participation in the civic cult. The crucial development was the imposition, following the Jewish revolt, of the fiscus Judaicus. This empire-wide tax placed the issue of Jewish identity in sharp relief and severely curtailed "the possibility of existing in a religious no-man's-land" such as that which characterized the Gentile believers-in-Jesus (223). The Jesus-believing Gentiles of Antioch found themselves in the peculiar position of having to publicly identify themselves as Jews subject to the tax in order to avoid prosecution for neglect of the cult, even as such an identity was denied them within their own community. The resulting tension in a group thus "deprived of all social and religious identity" (223) led to the formation of a social movement aimed at the creation of a new collegium: one entirely separate from Judaism but the true heirs, nonetheless, of the ancient (and thus legitimate) heritage claimed by Jews. The adoption of anti-Jewish rhetoric by Ignatius and in so much of the subsequent Christian literature was a key strategy in this effort.

This is a highly original and provocative study. Its relentlessly sociological approach and apparent lack of any underlying Christian (or Jewish) apologetic make this work a breath of fresh air in the perennial discussion of the separation of Judaism and Christianity. It is also, however, frequently quite speculative. To some degree this is unavoidable, given the state of the sources. Nor is it always a problem. What Zetterholm often has in his favor is at least some clearly articulated theoretical ground for his various suggestions, and the study is at its best when reconstructing general sociopolitical contexts. But where specific theoretical justification is lacking, particularly in the case of the detailed points that get closer to the specific theses of the book, the reader may become a bit more uneasy. Thus, for example, the account of the range of Jewish assimilation in Antioch in general in chapter 3 is quite persuasive, but the specific point about a Christian synagogue in Antioch - while not implausible - is rather less well-grounded. One would in any case like to have seen some discussion of what we can know about the number of "Jesusbelievers" in Antioch in any given period. Is it entirely out of the realm of possibility that Jewish Jesus-believers, like the Gentile ones in Paul's orbit, assembled as a community primarily in private households?

Similar concerns arise in the crucial chapters 4 and 5. Chapter 4's general thesis that James viewed the Gentiles essentially as "God-fearers" while Paul did not seems to me to be quite to the point. But Zetterholm's detailed reconstruction becomes unnecessarily complicated as a result of its positive assertion of the historicity of the apostolic decree. Even if Luke-Acts' account of this decree reflects a first-century Jewish discussion, and

This review was published by RBL (C2004 by the Society of Biblical Literature. For more information on obtaining a subscription to RBL, please visit http://www.bookreviews.org/subscribe.asp. 
granting the point that Paul himself reveals a certain squeamishness about food offered to idols in 1 Cor $8-10$, this is hardly a positive case for asserting the historicity of a formal agreement between Paul and Jerusalem on the matter-particularly given Paul's silence on the issue in Gal 2 and his explicit statement that nothing was added to his mission except the stipulation regarding the collection (Gal 2:6, 10). In fact, the assumption of an agreement about Gentile dietary restrictions in Jerusalem only makes the subsequent dispute about common meals in Antioch more puzzling - especially if, as Zetterholm seems to suggest, the decree itself had reflected "a prevalent halkhah in Antioch" (160)! Similarly, chapter 5's reconstruction of the general sociopolitical situation faced by Jesus believers after the imposition of the fiscus Judaicus is in the main quite illuminating. But given the crucial importance of the point to the book's overall thesis, Zetterholm's ultimate inability to produce explicit evidence for an Antiochene attempt to establish Gentile Christianity as a separate collegium is troubling (see 219-22).

As with any study that represents a radical rethinking of major issues, and particularly in matters where the primary evidence is thin, this book will no doubt elicit such criticism on a number of such points. There is nonetheless much to be learned from this volume. Between its theoretical sophistication, its relentless attention to social realities, and the seemingly apologetic-free challenge it presents to traditional readings of Christian origins, this book deserves a wide hearing among historians of early Christianity—highly recommended. 